\title{
'Human factors' board releases position paper
}

\author{
The National Advisory Board for Human \\ Factors in Dentistry (NABHF) has marked \\ its launch by releasing their position paper
}

\author{
titled Human Factors and Patient Safety in \\ Dentistry.
}

Established in July 2018, the Board has

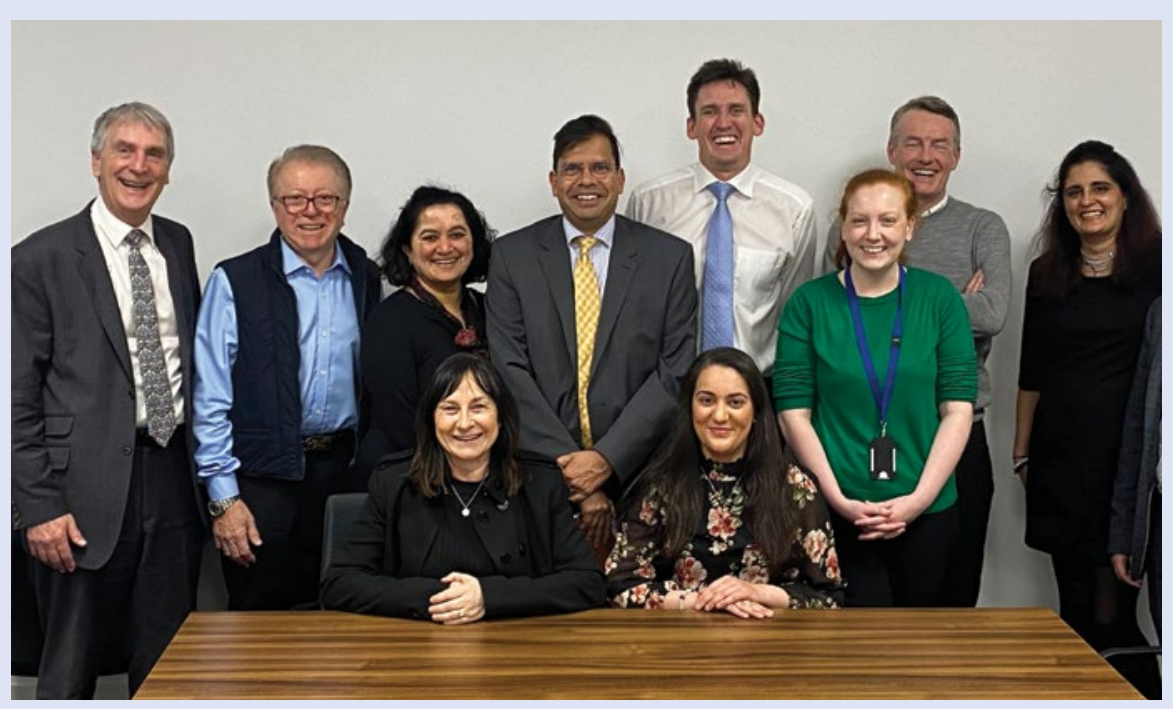

Some of the representatives of the NABHF. From left to right: Peter Dyer, Cemal Ucer, Ulpee Darbar, Fiona Ellwood, Len D'Cruz, Simon Wright (Chair), Priya Chohan, Hannah Pugh, Shareena Illyas broad representation from all sectors of the profession and is the only forum of its kind which brings together expert representation from the regulator, academia, indemnifiers, educators, researchers, secondary and primary care, dental care professionals and specialists.

The Board's mission is to 'advise and raise awareness and understanding of human factors to enhance safety, quality, health and wellbeing for patients and dental teams in all sectors'.

The paper highlights the importance of the multitude of factors embraced under the term 'human factors', which can influence the quality and efficiency of the provision of dental care and the need for openness using a root cause analysis approach to promote learning from 'mishaps'.

www.humanfactors.dental

\section{Donate waste metal for underprivileged children}

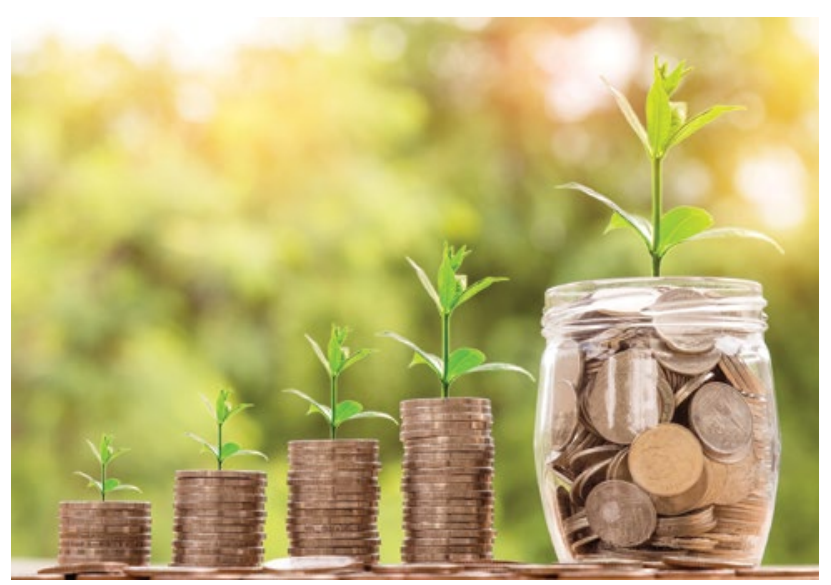

The first melt from 2018, which relied on the contribution of a handful of practices, went to Barnardo's, the oldest children's charity in the UK. They support vulnerable or neglected children from the early years until they reach adulthood, working hard and ensuring

Gold For Kids is a charitable foundation founded by dentists that raises money for underprivileged children in the UK. It does this through the melting of discarded precious restorations used in dentistry and old jewellery.

After removing a precious crown or restoration, you inform the patient of its potential value and give them the option to donate it to children's charities through Gold For Kids. they have the confidence to reach their full potential and triumph in their lives.

Gold For Kids is continuously looking to expand and grow in different areas of the UK and the rest of the world. Whether you think you could take Gold For Kids to your area, have an idea that could contribute to the project, or you simply would like to donate your waste metal, get in touch by emailing info@goldforkids.org or visiting www. goldforkids.org.

\section{Documenting COVID-19 at the National Library of Scotland}

The National Library of Scotland is

documenting the impact of the pandemic on Scottish business and the economy as part of its legislative mandate to collect, preserve, and protect documents that reflect Scotland's heritage.

When it is safe to do so, the National Library of Scotland is appealing to Scottish businesses to send it copies of the printed materials they have produced to provide the public with information about their changed business operations, such as business reports, newsletters, posters, flyers and leaflets.

By sending these, you will be contributing to a Coronavirus collection at the National Library that will be used to help people to understand this significant point in history.

Please let the Library know what print materials you have available to send by email to acq-mail@nls.uk so that it can retain a contact with you. 